\title{
University Enrolment in Canada 1951-83 and Beyond**
}

\author{
JOHN VANDERKAMP*
}

\begin{abstract}
Canadian university enrolment has increased dramatically over the last three decades. This paper discusses the time pattern of university participation rates and the variations across provinces in the light of economic analysis. $A$ number of potentially important factors are examined. While cost factors, tuition fees and student aid, have changed significantly, it. is argued that their quantitative impact is unlikely to account for a major part of the enrolment increase. Because university enrolment leads to additions to the stock of educated labour the paper analyzes the relations between stocks and flows. It is concluded that continuing participation rates at recent levels are only compatible with fairly rapid growth in the stock demand for highly educated labour over the next half century. The rise in community colleges since the late sixties presents a complicated factor, in part because in some provinces these colleges provide university transfer programs. It is likely that the slow-down in university participation rates during the seventies is at least in part attributable to the growth of the college system as a 'competitive' alternative. It is also argued that the increase in the size of the youth cohort contributed to this slow-down. Despite the conventional wisdom, the impact of unemployment on university enrolment rates is not easy to detect.
\end{abstract}

\section{RÉSUMÉ}

Depuis une trentaine d'années, les inscriptions dans les universités canadiennes ont augmentë considérablement. Dans cet article, nous analysons la courbe dans le temps des taux de participation universitaire et les variations selon les provinces

* Dean, College of Social Science, University of Guelph

** This paper is based on a public lecture given at the University of Alberta in March 1984, while I was a Distinguished Visiting Professor for the month. The paper provides an overview of the main issues and factors which are addressed in a technical paper reporting on an empirical model of enrolment, a preliminary version of which was given at the annual conference of the Canadian Economics Association in May 1984 in Guelph. I am grateful to Edward Sheffield and A.L. Darling for their comments and also to two anonymous referees. 
a la lumière d'une analyse économique. Nous examinons un certain nombre de facteurs éventuellement importants. Même si les les facteurs-coûts, les frais d'inscription et l'aide financière aux étudiants ont changé notablement, on peut dire pourtant que leur impact quantitatif ne peut pas expliquer la plus grande part de l'augmentation des inscriptions. Puisque les inscriptions universitaires finissent par ajouter à l'offre en main-d'oeuvre scolariseé, nous analysons dans notre article les relations entre l'offre et l'écoulement de cette main-d'oeuvre. Il faut considerer que le maintien des taux de participation au point actuel n'est compatible qu'avec une croissance assez rapide de la demande en main-d'oeuvre hautement scolarisée durant la deuxieme moitié du siècle. De plus, l'apparition des collèges communautaires depuis la fin des années soixante constitue un facteur de complication, en partie parce que, dans certaines provinces, ces colleges offrent des programmes d'équivalences universitaires. Il est probable que le ralentissement des taux de participation universitaire durant les années soixante-dix peut être en partie attribué à la croissance du système collégial comme compétiteur. On peut croire aussi que l'augmentation du groupe des jeunes a pu contribuer à cette diminution. Malgré ce que l'on croit généralement, il n'est pas facile de détecter un impact du chômage sur les inscriptions universitaires.

\section{INTRODUCTION}

There has recently been considerable concern about the possibility of a decline in university enrolment over the next fifteen years. The forecasts which give rise to this concern have generally been based on demographic factors, and in particular on the decrease in the university age-group resulting from the drop in birth-rates during the 1960's. A good example is the 1983 forecast by the Council of Ontario Universities (COU 1983) which indicates a 20\% decline in Ontario's university enrolment over the next 15 years (Foot 1981).

The academic concern about such forecasts has generally centered on two aspects. First, a sustained pattern of decline in enrolment will likely result in reduced levels of funding for universities which will then have difficulties in making ends meet because of sizeable fixed commitments to programs and facilities. Second, even if the financial aspect can be managed, the inevitable consequence of a declining student-base is the lack of turnover in academic positions. This will result in an aging faculty complement and possible sclerosis of the academic arteries (Peter Leslie 1980).

A useful step in evaluating such doom-and-gloom forecasts is the analysis of past trends in university enrolment. The approach taken in this analysis is that of an economist who sees higher education as an important human capital investment This is not to deny that social forces are significant, or to argue that the only reason students enrol in universities is to get a job or more money. These factors, including differences in background and ability and differences in taste, will modify the nature of economic responses and will need to be taken into account 
in the analysis. ${ }^{1}$ In my view too much of the recent discussion of enrolment has accepted as fact that because participation rates have been some number, say $15 \%$, in the recent past they are bound to remain at that level for the next 20 years.

\section{PATTERNS OF PARTICIPATION RATES}

In analyzing university enrolment trends I shall focus on participation rates, which measure university enrolment in relation to a particular university-age cohort. Enrolment, as a matter of mathematical identity, is the product of the participation rate, total population size, and the proportion of total population in the university-age cohort. Over the last thirty years the Canadian population has roughly doubled and the participation rate has roughly tripled; the universityage cohort size, relative to total population, has risen from $7.8 \%$ in 1951 to $9.6 \%$ in 1983. The result is that university enrolment almost increased to six-fold its original level over the last thirty years. In 1983 full-time undergraduate enrolment in Canada reached about 400,000 students. Clearly the most interesting and variable component of the above identity is the participation rate and the discussion will therefore concentrate on it.

The definition of the participation rate is the ratio of full-time undergraduate enrolment to the university-age population. The normal practice is to use the 18.24 year age-group as the university-age cohort in relation to total university enrolment, but this is somewhat too broad in relation to undergraduate enrolment and it does not take sufficient account of the differences between the educational systems in the various provinces (see Table 1 notes). It is important to remember that the age-span used here is narrower than usual which means that the participation rates reported here are approximately 1.4 times the usual rates which use the 18-24 age-group as the denominator.

It should be noted that our participation rate constitutes a simple ratio in

\begin{tabular}{|c|c|c|c|c|c|c|c|c|c|c|c|c|c|}
\hline \multicolumn{14}{|c|}{$\begin{array}{l}\text { TABLE } \uparrow \\
\text { Full.time Undergraduate Participation Fates (\%) }\end{array}$} \\
\hline & \multicolumn{3}{|c|}{ Canada } & \multirow[t]{2}{*}{ Nfid. } & \multirow[t]{2}{*}{ P.E.I. } & \multirow[t]{2}{*}{ N.S. } & \multirow[t]{2}{*}{ N. $B}$. & \multirow[t]{2}{*}{ Que. } & \multirow[t]{2}{*}{ Ont. } & \multirow[t]{2}{*}{ Men, } & \multirow[t]{2}{*}{ Sask. } & \multirow[t]{2}{*}{ Alb. } & \multirow[t]{2}{*}{ B.C. } \\
\hline & $T$ & $F$ & $M$ & & & & & & & & & & \\
\hline $1951-52$ & 6.2 & 3.6 & 8.9 & 1.3 & 4.4 & 7.8 & 5.4 & 6.8 & 6.1 & 7.4 & 4.5 & 3.9 & 8.1 \\
\hline $1955-56$ & 7.2 & 4.2 & 10.2 & 1.7 & 4.6 & 9.4 & 7.2 & 7.8 & 6.8 & 8.4 & 6.0 & 4.9 & 9.4 \\
\hline $1959-60$ & 9.5 & 5.7 & 13.2 & 2.9 & 8.4 & 10.6 & 9.8 & 10.9 & 8.7 & 10.3 & 9.2 & 6.9 & 11.4 \\
\hline $1963-64$ & 12.8 & 9.0 & 16.6 & 5.5 & 10.9 & 13.5 & 13.2 & 15.1 & 11.2 & 13.2 & 13.0 & 10.0 & 14.7 \\
\hline $1967-68$ & 15.? & 11.3 & 19.0 & 8.8 & 15.2 & 15.9 & 15.3 & 16.6 & 14.0 & 16.0 & 15.7 & 14.1 & 16.2 \\
\hline $1971-72$ & 15.3 & 11.8 & 18.9 & 12.7 & 18.1 & 22.4 & 18.0 & 10.0 & 18.2 & 18.1 & 18.1 & 17.8 & 13.6 \\
\hline $1975-76$ & 15.5 & 13.2 & 17.7 & 10.1 & $\uparrow 3.3$ & 21.6 & 16.0 & 10.9 & 19.2 & 18.0 & 15.9 & 15.9 & 13.0 \\
\hline $1979-80$ & 14.3 & 13.1 & 15.5 & 10.7 & 11.5 & 20.2 & 15.1 & 11.8 & 17.5 & 15.2 & 14.8 & 12.0 & 11.4 \\
\hline $198 \uparrow-82$ & 15.1 & 14.2 & 16.0 & 12.3 & 12.1 & 22.1 & 17.0 & 12.3 & 18.6 & 16.2 & 16.2 & 11.9 & 11.4 \\
\hline $1983-84$ & 16.8 & 15.9 & 17.6 & 12.7 & 13.9 & 25.7 & 19.4 & 13.6 & 19.3 & 19.8 & 19.1 & $i 5.2$ & 13.4 \\
\hline \multicolumn{14}{|c|}{$\begin{array}{l}\text { Note: Full-time enrolment including teachers college enrolment as a percentage of the eppropriate university age cohort. The university age cohort is } \\
\text { the five year age span which accounts for } 70-80 \% \text { of the actual agespan of full-time undergraduates. The five year age groups are as follows: } \\
\text { (1) } 17-21 \text { for Newfoundiand, (2) } 18-22 \text { for Maritimes and the four Western provinces, (3) } 19-23 \text { for Ontario and Quebec. }\end{array}$} \\
\hline SOURCES: & \multicolumn{13}{|c|}{$\begin{array}{l}\text { Enrolment i) Universities: Enrolments and Degrees. Education, Science and Culture Division, Statistics Canada, 81-204. } \\
\text { ii) Survey of Highar Education, Education, Science and Culture Division, Statistics Canada. } \\
\text { iii) Historical Compendium of Education Statistics, Education, Science and Culture Dlvision, Statistics Canada, 81.568. } \\
\text { Population i) Intercensal Estimates of the Population by Sex and Age. Cenada and the Provinces, June 1st 195i-1983, Demography } \\
\text { Division, Statistics, Canada, 91-202. }\end{array}$} \\
\hline
\end{tabular}


which the numerator and denominator are obtained from two different sources (Darling 1980), and this presents some problems. Foreign students are included in the enrolment figures, and any changes in the proportion of these students in Canadian universities will obviously affect the measured participation rate. ${ }^{2}$ Second, some Canadian students attend university outside Canada. Third, some students attend university outside their home province. ${ }^{3}$ Fourth, if there is a change in the age composition of undergraduate students, e.g. due to decisions to postpone university education, then the chosen age-cohort will become less relevant. Fifth and finally, our participation rate refers to full-time undergraduates and does therefore not take account of part-time and graduate enrolment (Foot 1981).

The broad pattern of participation rates over the period 1951-83 is shown in Table 1. The general pattern shows a slow rate of growth in participation rates during the early fifties followed by rapid growth from 1955.71, and a period of little growth with fluctuations during the seventies. Broadly speaking this general pattern applies to all of the provinces, but the following exceptions should be noted. Quebec's participation rate declined sharply from 1967.71 associated with the introduction of the CEGEP system. The British Columbia rate reached a peak in the years 1965-68 followed by a general decline which moved this province from near top to near bottom rank over the next 16 years.

The period since 1971 has been marked by fluctuations in all provinces and for most provinces the 1983 rate is at a somewhat higher level than in 1971 . I have already noted B.C. as an exception, and Alberta and P.E.I. rates also display strong downward trends since 1971. On the other hand, Quebec's participation rate has been on the increase since 1971. The overall pattern displays sufficient variation to make one skeptical about simplistic forecasts. Table 1 also shows male and female participation rates. Although the female rate has had a much stronger upward trend over the whole period, both rates display somewhat similar fluctuations since the late sixties.

\section{IMPORTANT FACTORS AND THEIR PATTERNS}

In this section I shall briefly indicate the patterns of some of the main factors which may have influenced the variations in participation rates. The choice of factors to be discussed is of course, determined by my general approach, the human capital framework. In this context the principal determinant of individual investment decisions is the prospective rate of return. Little direct evidence is available on this variable for Canada (but see Freeman 1981). But we do have information on two important cost items: tuition fees and student aid. Moreover the rate of return to a university education is strongly affected by changes in the demand for university-educated labour. Since this demand notion is a stock concept while university enrolment leads to a flow into this labour market, there will have to be some consideration of this stock-flow interaction, which will be undertaken in the next section. The rate of return to a university educa- 
tion is also affected by competing educational channels such as community colleges. This subject is closely tied to institutional arrangements and will be discussed under that heading.

It will be noticed that individual tastes and preferences and public attitudes do not feature in my list of factors. The principal reason is that there are no objective quantitative data on this subject. In my view the impact of the Sputnik event or of the mid-sixties pronouncements by the Economic Council of Canada per se are grossly overblown in the standard commentaries on the trens of education in the last three decades. It is, of course, another matter if such events contributed to policy changes e.g. regarding student aid.

In the analysis I.am also implicitly assuming that participation rate variations result from decisions of individual students not from university decisions e.g. regarding quotas and enrolment limits. There is no denying that such restrictions exist in a number of programs, but I assume that on an overall basis there has been sufficient accessibility. We can think of a student first making the decision to go to university, and if the decision is positive the student then decides on program and area of specialization. In that case any restrictions will primarily affect the second decision not the enrolment decision. On the other hand, lower admission standards and grade inflation in the secondary schools may have made more students eligible to consider an enrolment decision. Based on the data reported in the previous section I am assuming that most students attend university in their home province (see fn. 3 ). The reasons are associated with costs and special features of the provincial education systems. This implies that provincial policies regarding fees, student aid, and competing postsecondary channels matter in the student's decision to enrol.

Table 2 shows the pattern of tuition fees in real terms (1971 dollars) for the period from 1951 to 1983 . The overall Canadian pattern of tuition fees shows little change during most of the fifties, rapid increases from 1958 to 1968 , followed by a fairly steady decline since then. The provincial patterns are rather interwoven and not all the provinces follow the average Canadian pattern. In particular, real tuition fees reached their peaks at different points: in 1965 for P.E.I., Nova Scoita, New Brunswick and B.C., in 1966 for Newfoundland, in 1967

\begin{tabular}{|c|c|c|c|c|c|c|c|c|c|c|c|}
\hline & Canada & Nfid. & P.E.I. & N.S. & N.B. & Que. & Ont. & Man. & Sask. & Alb. & B.C. \\
\hline $1951-52$ & 407 & 161 & 172 & 306 & 384 & 448 & 466 & 301 & 288 & 257 & 358 \\
\hline $1955-66$ & 400 & 160 & 170 & 304 & 381 & 444 & 462 & 299 & 286 & 255 & 355 \\
\hline $1959-60$ & 419 & 226 & 209 & 488 & 495 & 409 & 480 & 357 & 290 & 330 & 404 \\
\hline $1963-64$ & 482 & 369 & 389 & 603 & 615 & 486 & 531 & 389 & 276 & 421 & 448 \\
\hline $1967-68$ & 513 & 463 & 463 & 694 & 659 & 434 & 627 & 434 & 358 & 376 & 528 \\
\hline $1971-72$ & 507 & 500 & 550 & 577 & 605 & 536 & 537 & 425 & 418 & 400 & 428 \\
\hline $1975-76$ & 387 & 361 & 433 & 520 & 485 & 343 & 437 & 307 & 338 & 289 & 309 \\
\hline $1979-80$ & 326 & 330 & 418 & 400 & 413 & 248 & 371 & 298 & 343 & 288 & 280 \\
\hline $1981-82$ & 316 & 291 & 401 & 433 & 401 & 201 & 386 & 283 & 312 & 255 & 249 \\
\hline $1983-84$ & 323 & 321 & 432 & 475 & 450 & 162 & 398 & 254 & 313 & 277 & 324 \\
\hline
\end{tabular}

Note: This series pertains to tuition fees (deftated by the Consumer Price Index 1971=100) for undergraduate students enrolled fult-time in arts and science programs at the largest universities in each province.

SOURCE; Financial Statistics of Education. Post-Secondary Division, Education Stience and Culture Division, Statistics Canada, 81-208. 


\begin{tabular}{|c|c|c|c|c|c|c|c|c|c|c|c|}
\hline \multicolumn{12}{|c|}{$\begin{array}{l}\text { TABLE } 3 \\
\text { Real Student Aid per Student (1971 dollars) }\end{array}$} \\
\hline & Canada & Nild. & P.E.I. & N.S. & N.B. & Que. & Ont. & Man. & Sask. & Alb. & B.C. \\
\hline $1951-52$ & 72 & 138 & 40 & 10 & 19 & 139 & 58 & 16 & 22 & 18 & 29 \\
\hline $1955-56$ & 55 & 101 & 129 & 5 & 10 & 89 & 60 & 28 & 17 & 17 & 25 \\
\hline $1959-60$ & 78 & 189 & 70 & 55 & 12 & 87 & 77 & 56 & 86 & 230 & 5 \\
\hline $1963-64$ & 139 & 192 & $\mathbf{2 6}$ & 78 & 84 & 184 & 124 & 81 & 129 & 185 & 83 \\
\hline $1967-68$ & 366 & 446 & 125 & 293 & 313 & 362 & 522 & 188 & 141 & 319 & 214 \\
\hline $1971-72$ & 559 & 1035 & 791 & 487 & 485 & 763 & 570 & 490 & 390 & 303 & 389 \\
\hline $1975-76$ & 555 & 779 & 654 & 486 & 400 & 851 & 499 & 528 & 448 & 341 & 490 \\
\hline $1979-80$ & 558 & 540 & 428 & 402 & 352 & 864 & 526 & 399 & 383 & 330 & 449 \\
\hline $1981-82$ & 589 & 485 & 330 & 356 & 362 & 858 & 587 & 315 & 325 & 351 & 383 \\
\hline $1983-84$ & 388 & 478 & 323 & 286 & 464 & 510 & 378 & 278 & 342 & 311 & 321 \\
\hline
\end{tabular}

for Ontario, in 1968 for Alberta, in 1969 for Manitoba and Saskatchewan, and in 1971 for Quebec. While in all provinces tuition fees declined during the 1970's the drop was largest in Quebec which now has the lowest fees in the country.

On the surface there appears to be little if any (negative) relationship between the patterns of enrolment and tuition fees. In particular, participation rates increased rapidly from 1955 to 1971 , a period when tuition fees were increasing, and participation rates fluctuated with little trend during the seventies when real tuition fees were decreasing. In most provinces tuition fees have become a political issue of some significance, and in fact some people argue that fees have become an item of provincial social policy. In the present era of financial restraint we may well see a reversal of recent trends and the proposed fee hikes in British Columbia may be an early signal.

Table 3 presents the pattern of real student aid (also in 1971 dollars) per fulltime undergraduate student. This measure of student aid includes bursaries, scholarships and subsidies on student loans. While these series appear to contain a certain amount of random variations, some general patterns are clearly discernible. The average Canadian student aid figures were at very low levels and showed little change throughout the fifties, they increased slowly in the early sixties, followed by a very rapid expansion between 1965 and 1970, and little apparent trend since then. The provincial series tend to interweave although they all share the rapid rise in student aid during this 1965.71 period, which is no doubt linked with the launching of the Canada Student Loans Plan by the Federal Government in 1964.

There is some broad correspondence between the enrolment and student aid patterns, although it would seem difficult to explain the rapid rise in participation rates from 1955 to 1965 since student aid increased rather slowly during that time. It might be argued that the introduction of the CSL-plan followed by provincial initiatives in this area prolonged and intensified the growth in participation rates during the period 1965-71, and that the lack of growth in participation rates during the most recent decade was caused by the no-growth trend in student aid. It is also tempting to explain the steady growth in Quebec's partici- 
pation rate since 1971 in terms of fee reductions and aid increases which have occurred during that time, resulting in Quebec having the lowest tuition fees and the highest student aid figures in the country. On the other hand, the positive association between student aid and participation rates does not work well in other jurisdictions, in particular for Newfoundland, but also for Alberta and British Columbia. ${ }^{4}$

The next factor to be considered is the stock demand for educated labour and this is a difficult subject. For one thing good data are a problem. I estimate that persons with university degrees have increased from about $2.5 \%$ of the population of working age in 1950 to about $8.5 \%$ in 1980 with a large part of the increase occurring in the seventies rising to about $10 \%$ in the mid-eighties (Von Zur-Muehlen 1982). We do have somewhat better data on so-called highly qualified manpower (HQM), which includes managerial, professional and technical occupations. It should be noted this HQM-category does not include all occupations for which a university education may be required, and, of course, not all persons classified in the HQM-category have a university education. Nevertheless, the HQM-group appears to be quite a reasonable approximation for the notion of a stock of more educated labour. As a percentage of employment the HQM-group has fairly steadily increased from $15.7 \%$ in 1951 to about $28.3 \%$ in 1983. An important subgroup of HQM is the occupation of teachers which increased from $1.9 \%$ of total employment to a peak of $3.4 \%$ in 1970 followed by a declining trend to $2.5 \%$ in 1983 .

The phenomenon of increasing stock demand for educated labour is related to increasing technological sophistication and increasing capital intensity. While unskilled labour has been replaced by capital, it is widely accepted that more educated labour is complementary with capital. During the last thirty years the overall capital-labour ratio has increased from about $\$ 10,000$ to about $\$ 25,000$ per worker (in 1971 dollars). Accompanying the increasing capital intensity of the Canadian economy there has been an increased demand for a wide range of occupations, including engineering and technical occupations but also in managerial occupations and in business and government services. My assessment is that these increases in the demand for more educated labour have been fundamentally important in stimulating university participation rates. The Foot and Pervin (1983) model includes a real income variable which may be interpreted in this context as a proxy for the stock demand increases associated with technological advances.

The last factor to be discussed briefly involves institutional arrangements. This term covers a wide range of events some of which were relatively straightforward re-organizations of provincial education systems, others involved the creation or expansion of competing channels for postsecondary education. The proposed disappearance of grade 13 in Ontario will have a temporary, although very important, impact on university participation rates in the late eighties (COU 1983). And the introduction of grade 12 in Newfoundland in 1983 has already resulted in a temporary decline in enrolment. Since the new CEGEPs in fact 
took over the first year of university, this had a major impact on university participation rates. This transfer route of entry through a community college is also open in Alberta and B.C., but it is not the required route in those provinces.

The introduction of the CEGEP-system also had another major impact by creating an alternative channel for obtaining a postsecondary education. The CEGEP provides the alternative to university and it provides the only way of entering university, with the result that only in Quebec does the enrolment of the college system far exceed that in the university system. In Alberta and British Columbia, and in Ontario the community college systems are also well developed, although less important than in Quebec. In Ontario the college system was specifically designed to provide an alternative to the university system. In Nova Scotia, New Brunswick, Manitoba and Saskatchewan the college systems are not particularly important.

\section{ANALYSIS AND POSSIBLE EXPLANATIONS}

The analysis proceeds by way of five questions:

\section{Were government policies related to student aid and tuition fees responsible for the upswing in participation rates during the period 1955-70?}

The answer is that these policies may have contributed to the participation rate pattern but they can hardly have accounted for a major part of the upswing. My reasons are three-fold. First, I have already commented about the lack of association between the various time patterns. If we combine real tuition fees and real student aid (e.g. subtract aid from fees) we observe little change before 1965 and little change after 1975, with most of the decrease in out-of-pocket costs occurring during the 10 years 1965-75. Second, although these costs decreased substantially it is not clear that the drop was sufficient even to account for the increase in the participation rate in the period 1965-75. It is true that for the 'average' student at a Canadian university the fees-aid costs of a 4-year program went from $\$ 1480$ to $-\$ 670$ (negative because in the seventies average aid exceeds average fees) in real terms. This is a very sizeable switch but it should be considered in relation to total costs: The major part of an investment in a university education consists of foregone earnings, i.e. the amount of income which a potential student could earn by taking a job after high school. Taking these foregone earnings into account I estimate that the total cost of a 4-year degree program was reduced by about $10 \%$ during the ten years $1965-75$. During the same time the Canadian participation rate increased from $12.7 \%$ to $15.4 \%$, or a $20 \%$ increase. This seems a relatively large response rate. In their empirical model, Foot and Pervin (1983) use a grants-variable (real operating grants per student) to reflect the 'price' of postsecondary education, but this represents an indirect measure of private costs and it is probably better viewed as a measure of quality.

But, thirdly, there is a more fundamental problem with this approach since we would expect cost reductions to have an impact on salary differentials between the university-educated work force and high school graduates. In other words, in 
the long run one cannot expect a reduction in the total costs of a university education to lead to a permanently higher rate of return to this education. If we assume the full cost reduction which occurred in the period 1965-75 to be reflected in reduced income differentials, then we can ask by how much this would have increased the total stock demand for university degrees in the potential work force. The answer appears to be that the $10 \%$ cost reduction would have resulted in a rise in the stock demand of less than half a percentage point. ${ }^{5}$ Since during that time period the stock of people with degrees as a percentage of the labour force population increased by about $3.5 \%$, the cost reduction associated with fees and aid can only account for a small part of it. This leads us naturally to the next question in the analysis.

\section{To what extent did the $\mathbf{1 9 5 5 - 7 0}$ increase in participation rates represent an adjustment in the required stock of university educated labour?}

This presents a difficult question and I shall only deal with a few cases to explain the nature of the stock-flow relationship. For this purpose it is important to distinguish between replacement investment, and new investment or net additions to the stock of human capital. In the context of a university education this means that some graduates replace people who are retiring from the work force while others constitute a net addition to the stock of people with degrees. In view of the figures discussed in the preceding sections of this paper it must be clear that most of the university enrolment over the last few decades has represented new investment in human capital.

If the proportion of the labour force population with a university degree were to stabilize at $10 \%$ this would require a steady-state participation rate, for replacement purposes, of about $8 \% .6$ This represents just over half the level of participation rates experienced in recent years. On the other hand, if the participation rate were to remain indefinitely at $16 \%$ this would eventually, e.g. in 4 decades, result in a stock of university-educated labour (persons with degrees) equivalent to about $20 \%$ of the labour force population. This latter scenario may not seem unreasonable in view of what has happened in the last few decades. But it does require a continuing increase in the stock demand for educated labour which is somewhat higher than our experience in the last three decades. And this in turn requires a continuing process of technological development and increasing industrial sophistication over the foreseeable future.

In the preceding paragraph we were concerned with university enrolment solely for replacement of human capital. But during the last thirty years the stock of persons with degrees (as percentage of labour force population) has expanded at an average rate of 2 percentage points per decade (from about $2.5 \%$ in 1951 to about $8.5 \%$ in 1981). Suppose that this was a once-for-all change which will not continue into the future and the proportion with degrees will stabilize at $10 \%$ of the labour force population. For that case we can roughly trace out the participation rate growth over the period since 1951 with of course most of the enrolment in the sixties and seventies particularly being related to new additions to the 
stock. This once-for-all case may trace the past pattern of participation rates reasonably well, but it presents a disturbing picture for the future since in the new steady-state the participation rate is bound to fall to $8 \%$. It is probably correct to argue that 'nature does not make jumps' and that therefore this case is unrealistic. On the other hand some of the pessimism will survive in the next less extreme case.

Obviously before 1950 the stock of people with degrees was growing slowly, followed by a rapid growth period particularly during the sixties and seventies. Suppose that in the foreseeable future the stock demand were to grow at one percentage point per decade, i.e. it would take a century for the $10 \%$ stock figure to become $20 \%$ of labour force population. That slower growth path would be compatible with participation rates in the $12 \%$ range. Initially more than half of the associated enrolment would constitute new additions, but after a few decades replacement would be the major component. This may not seem an unreasonable scenario although it does suggest a downward adjustment in participation rates from recent levels.

What would occur if prospective students decided to enrol regardless of what happens to the required stock? This would result in a drop in the rate of return to a university education and a narrowing of salary differentials between universityeducated labour and high-school graduates. There is considerable evidence for the U.S. that salary differentials have narrowed, and the rate of return reduced, from the late sixties to the mid-seventies and beyond (see Freeman 1981). These trends appear to be related to a slow-down in the growth of professional employment and to the baby-boom cohort size; I shall return to this last issue shortly. Such a reduced rate of return could become permanent if there has been a change of tastes and preferences, which might take the form of increasing preferences to work in certain occupation categories (requiring a university degree). Such a trend might result from the background of parents who are increasingly more likely to have had a university education. It should be emphasized though that such a change in preferences will reduce job opportunity and salary differentials, which now favour university graduates, and it may even result in disappointment if the chosen professions become crowded.

\section{How important was the rise in Community Colleges in slowing down univer- sity participation rates during the seventies?}

There is considerable evidence that the expansion of the Community College System since the late sixties has contributed to the recent trends in university participation rates. The growth in total postsecondary enrolment in the decade after 1965 was roughly the same as in the decade before, after allowance for population growth (see Statistics Canada 1978). Moreover, there appears to be a general, negative correlation between changes in university participation rates and college participation rates across provinces in the 1965.75 decade. In short, there seems little doubt that the pattern of participation rates since the late sixties is related to the development of Community College Systems, but this cannot 
explain all. Moreover, if one were to argue that the trend of total postsecondary enrolment will continue into the next few decades (with universities perhaps fighting for a larger share) then the previous part of the analysis relating to stocks and flows must be recalled with even greater interest.

\section{Was the baby-boom cohort responsible for the lack of growth in participa- tion rates during the seventies?}

The theoretical argument regarding this question proceeds as follows. The baby boom was a period of unusually high birth-rates from about 1946 to about 1960 which gave rise to a large university-age cohort during the period 1967-80. This produced a temporary supply shock, in terms of the number of potential students, and this shock may well have upset markets for educated labour. The argument is that it produced a larger disturbance for the university-educated labour market than for the market for high-school graduates per se (Welch 1979). The rationale is that university-educated labour market entrants take on considerably further training and learning on the job, a process in which the more experienced segment of this labour market is crucially involved. Because of this complementarity between experienced and inexperienced members of these university-level occupations, an unusually large entering cohort will depress these markets both in terms of salary differentials and job opportunities. There is indeed evidence for the U.S. (see Welch 1979 and Freeman 1981) that the 'baby-boom cohort' contributed to the lowering of relative earnings in the university-educated labour market; Dooley (1984) also presents some preliminary Canadian evidence for the 1970's which supports some of the results of Welch (1979).

The observed patterns of participation rates during the 1970's is certainly consistent with the hypothesis, but we have already seen with regard to the previous questions that there are alternative hypotheses. The issue is of some significance in connection with the outlook for participation rates during the next 15 years. Foot and Pervin (1983) obtain a (barely significant) negative coefficient for the cohort size, but their estimated impact of cohort changes on enrolment rates in Ontario over the next decade seem incredibly large, adding almost six percentage points.

\section{Are participation rates affected by unemployment?}

The past pattern of participation rates offers little evidence on this question. But by now it is conventional wisdom that there is a positive relation between unemployment and participation rates, and that the recent up-swing in participation rates is entirely attributable to higher unemployment. It is true that participation rates increased from a low point in 1979 to 1983 . But the unemployment rate was quite stable at about $7.5 \%$ during the years 1979 to 1981 , and the sudden rise to unemployment rates in the $12 \%$ range did not start until 1982 . Thus even in the recent period the patterns are by no means perfectly matched.

There is a reasonable theoretical argument which can be advanced why a temporarily depressed economy may stimulate university enrolment temporarily. 
An eighteen-year old potential student may decide that the job prospects for his or her age-group are poor for the next few years, and that therefore the major cost of attending university (foregone earnings) are likely to be low. The hard evidence on this hypothesis may not really be available until 3 to 5 years from now. Foot and Pervin (1983) find that the relative unemployment rate (youth to total) has a positive impact on the university enrolment rate for Ontario.

\section{CONCLUSIONS}

The foregoing discussion has shown that we are by no means clear on what forces shaped the pattern of university participation rates over the last three decades. Looking into the future becomes even more difficult since the future path of a number of the factors identified is not predictable with a great deal of certainty. Nevertheless, looking into the future is a good way of focussing our ignorance and uncertainty.

Two factors may make one optimistic about the future course of participation rates. First, the university-age cohort will decline over the next fifteen years, and if the hypotheses (discussed undér question 4) are correct then this should lead to some increase in the participation rate. Second, I assume that the institutional arrangements regarding other channels for a postsecondary education have stabilized and that there will be no new competition for the universities particularly from the Community Colleges. If the argument presented (in connection with question 3 ) is correct that the new competition from community colleges has had a negative impact on university enrolments during the last 15 years then we can expect some rebound of university participation rates.

There are two factors which may lead to some pessimism on this score. First, if the expected improvements in the Canadian economy over the remainder of the present decade are realized and lead to a steady reduction in unemployment rates, then participation rates may also decline. As I indicated there is little systematic evidence on this point but there may be some truth in the conventional wisdom. Second, the general pattern of government restraint may lead to real increases in tuition fees and a reduction in student aid. While such a prediction is fraught with uncertainty recent developments in British Columbia may be a bellwether in this regard. Such a development would have a depressing effect on participation rates.

The major uncertainty surrounds the factor which I have labelled the stock demand for university-educated labour. There is little doubt that technology will develop further, that industry and the public sector will become more sophisticated, and that capital intensity will continue to increase. The real question is how fast this process will take place by comparison with that of recent decades. If technological progress is rapid, participation rates may stabilize at recent levels or even increase. The main cause for optimism on this score is the so-called information technology revolution which is presently in its early stages. Quite a few people, who are close to these developments, predict that this revolution is 
much larger in impact over the next few decades than any technological developments which we have experienced in the recent past.

\section{FOOTNOTES}

1. A considerable amount of work in this area has been done in the U.S. (see Richard Freeman 1975 and 1981) and in the U.K. (see C. Pissarides' 1982). I was not aware of the recent Foot and Pervin (1983) paper when preparing this paper originally.

2. In the 1983 COU-report (Table 2, p. 9) foreign students are separately identified for 1978-79. For Canada as a whole they represent almost $10 \%$ of full-time undergraduate enrolment, roughly the same percentage.in all provinces except for P.E.I. and Newfoundland where they account for $5 \%$ or less.

3. The same table in the 1983 COU-report provides data on Canadian participation rates by home province. For most provinces the student flow across provincial boundaries roughly evens out, but Nova Scotia's home-province enrolment in 1978.79 is 'inflated' by about $15 \%$ due to out-of-province students, while more than $1 / 3$ of P.E.I.'s home-province students are enrolled in other provinces.

4. It may be argued that the costs of attending universities were also reduced by the expansion of the university system allowing more students to live at home, but such a cost reduction is not easy to quantify.

5. For this purpose $I$ assume that the rate of return to a university education remains the same before and after the cost reduction. Then the $10 \%$ reduction in total costs associated with a university education results in a $10 \%$ reduction in the salary differential between people with university degrees and high school graduates. If we then assume that the stock demand for university-educated labour has an elasticity of unity with regard to this salary differential, then the result will be a $10 \%$ increase in the number of people with degrees. In 1965 the proportion of the labour force population with degrees was about $4 \%$ so the cost reduction would increase this to $4.4 \%$.

6. For this purpose $I \mathrm{am}$ assuming that the annual number of first degrees granted is about $1 / 4$ of university enrolment (Von Zur-Muehlen 1982). I also assume a life expectancy for university graduates of 50 years which implies a steady-state turn-over rate of $2 \%$ per year. Finally, I assume that the university-age cohort constitutes $10 \%$ of the total labour force population which is the figure which is expected be obtained in the mid-nineties, although it is lower than actually observed over the last thirty years. For example, if $10 \%$ of the labour force population has a university degree, the replacement rate per year is $.2 \%$. This translates into a rate of $2 \%$ new degrees in terms of the university-age cohort, which in turn implies a participation rate of $8 \%$. The assumptions are rough-andready but adequate for the purpose of illustration.

\section{REFERENCES}

Council of Ministers of Education, Review of Educational Policies in Canada, 1975.

Council of Ontario Universities, Participation Rates and Future Enrolment in Ontario Universities, Toronto, September 1983.

Darling, A.L. The Impact of the Participation Rate - Whatever it is - on University Enrolment. Canadian Journal of Higher Education, 1980, 10(1), 37-56.

Dooley, M.D. Changes in the Relationship among Earnings, Education and Age for Canadian men: 1971-81. Paper given at the May 1984 Conference of the Canadian Economics Association. 
Foot, D.K. A Troubled Future? University Enrolments in Canada and the Provinces, in D.M. Nowlan and R. Bellaire (Eds.). Financing Canadian Universities: By Whom, For Whom? Toron to: O.I.S.E. Press, 1981.

Foot, D.K. \& Pervin, B. The Determinants of Postsecondary Enrolment Rates in Ontario. Canadian Joumal of Higher Education, 1983, 13(3), 1-22.

Freeman, R.B. Overinvestment in College Training? Journal of Human Resources, 1.0 (3), 287-311.

Freeman, R.B. Implications of the Changing U.S. Labor Market for Higher Education. Harvard Discussion Paper \#836, (July 1981).

Gilbert, S. Education, chapter 7 in Allan Tarowetz et al. (Eds.) Introduction to Sociology, Toronto Methuen, 1983, 265-305.

Glenny, L.A. Demographic and Related Issues for Higher Education in the 1980's . Journal of Higher Education, 1980, 51 (4), 363-380.

Leslie; P.M. Canadian Universities 1980 and Beyond. Ottawa, Association of Universities and Colleges of Canada, 1980.

Pissarides, C.A. From School to University: The Demand for Post-Compulsory Education in Britain. Economic Journal, 1982, 92, (3) 654-667.

Statistics Canada, Historical Compendium of Education Statistics, Ottawa, Supply and Services Canada, 1978 (cat. no. 81-568).

Statistics Canada, A Statistical Portrait of Canadian Higher Education, Supply and Services Canada, 1983, Ottawa.

Welch, F. Effects of Cohort Size in Earnings. 'The Baby-Boom Babies' Financial Bust. Journal of Political Economy, 1979,87, (Suppl.) S65-S97.

Von Zur-Muehlen, M. Past and Present Graduation Trends at Canadian Universities and Implications for the Eighties with Special Emphasis on Women and on Science Graduates. Statistics Canada, mimeo March 1982. 